\title{
Improving the environmental production of electrodes for solar panels
}

\author{
A. O. Patianova*, K. Yu. Ivanova, \\ L. G. Rogozhina, M. V. Kuzmin, V.L. Semenov \\ Chuvash State University named after I. N. Ulyanov, \\ 15 Moskovsky av., Cheboksary, 428015, Russia \\ email: alisa.patyanova@yandex.ru
}

\begin{abstract}
Biodegradable aminosiloxanes have been synthesized by the interaction of 3-aminopropyltriethoxysilane with monoethanolamine in the presence of a binary antioxidant and an alkali metal alcoholate. The synthesized compounds were used to develop flux compositions for tinning copper wire and producing electrodes for solar panels. The wetting ability, fluxing activity and biodegradability of the flux were investigated. The possibility of using a flux for hot tinning of copper wire is shown, which makes it possible to increase the environmental friendliness of the production of electrodes for solar panels.
\end{abstract}

Keywords: flux; lead-free solder; solar panels; electrode; tinning; copper wire; biodegradable aminosiloxanes

Received: 29.10.2020. Accepted: 09.12.2020. Published:30.12.2020.

(c) Patianova A. 0., Ivanova K. Yu., Rogozhina L. G., Kuzmin M. V., Semenov V. L., 2020

\section{Introduction}

Currently, the most attractive and promising of renewable energy sources is the use of photovoltaic modules [1]. The quality of photovoltaic modules directly determines the efficiency of solar energy production, so the production of photovoltaic modules becomes especially important [2-5]. A relatively large number of lead-free solders have been proposed for replacement of lead-based ones. Most of these alloys contain metals such as $\mathrm{Sn}$, In and $\mathrm{Bi}$, with the dominant Sn content [6]. Long-term reliability data is extremely important for the successful application of these alloys, namely properties such as the ability to withstand thermal fatigue, corrosion, changes in mechanical properties during thermal aging and the ability to withstand mechanical stress. Also the cost, manufacturability, availability, melting point and the effect of temperature on polymer components are important $[7,8]$. The most promising solder is a low-melting lead-free one based on tin and indium of POIN-52 grade, which is used to impart high physical, mechanical and operational properties. The product with high antifriction and wear-resistant properties to contacts with a low transient resistance and higher corrosive properties in acidic and alkaline solutions, as well as mineral oils, which is not typical for products made of pure metals is the result of using such alloy. The reason of using indium is its ability to reduce the oxidizability of alloys in the molten state, which is very important for increasing the reliability of final products. To ensure good 
adhesion between the tin or tin alloy and the copper wire manufacturers need to use a suitable flux [8].

A significant drawback of such fluxes is the impossibility of complete removal of its components from the brazed surface, which leads to its corrosion, as well as the inevitability of wastewater pollution with salts of heavy metals, amines and other substances when washing products after soldering. This process is environmentally harmful.

The aim of the work was to increase the environmentally friendly production of electrodes for solar modules by using harmless flux compositions that meet the existing requirements for solar modules' electrodes.

\section{Experimental}

Aminoalkoxysilanes I-III were prepared by reacting 3-aminopropyltriethoxysilane with monoethanolamine at different molar ratios in the presence of a binary antioxidant and an alkali metal alcoholate.
It is known that organosilicon compounds are biodegradable, they can increase the intensity of biological processes with oxidation of organic pollution of wastewater and thereby reduce the anthropogenic load on environmental objects [9].

For this, we synthesized aminosiloxanes, organosilicon compounds, which can reduce the corrosivity of the flux, improve the solder spreading, ensure the required fluxing activity, increase the contact angle with the tinning surface, reduce the surface tension and eliminate the solder surface oxidation and the base material to be tinned.

To this end, ( $v 1$, mol) 3-aminopropyltriethoxysilane, $\left(v^{2}, \mathrm{~mol}\right)$ pre-distilled monoethanolamine are loaded into a reactor equipped with a stirrer, the reaction is carried out in the presence of an antioxidant

Table 1

The structure and properties of aminosiloxanes

\begin{tabular}{|c|c|c|c|c|}
\hline Formula and name & $v_{1}: v_{2}$ & $\begin{array}{c}\text { Efficiency, } \\
\%\end{array}$ & $\mathrm{n}_{\mathrm{D}}^{20}$ & $\begin{array}{l}\text { IR spectrum, } v \text {, } \\
\qquad \mathrm{cm}^{-1}:\end{array}$ \\
\hline $\begin{array}{l}\stackrel{\left(\mathrm{O}-\mathrm{CH}_{2}-\mathrm{CH}_{3}\right)_{2}}{\stackrel{\mathrm{I}}{\mathrm{H}}} \mathrm{H}_{2} \mathrm{~N}-\mathrm{H}_{2} \mathrm{C}-\mathrm{H}_{2} \mathrm{C}-\mathrm{H}_{2} \mathrm{C}-\mathrm{Si}-\mathrm{O}-\mathrm{CH}_{2}-\mathrm{CH}_{2}-\mathrm{NH}_{2} \\
\text { 3-aminopropyl- (2-aminoethoxy) } \\
\text { diethoxysilane (I) }\end{array}$ & $1: 1$ & 89.7 & 1.4440 & $\begin{array}{l}3373,3294 \\
\left(\mathrm{NH}_{2}\right), 2974 \\
2927,2883 \\
\left(\mathrm{CH}_{3}, \mathrm{CH}_{2}\right) \\
1083(\mathrm{Si}-\mathrm{O}-\mathrm{C})\end{array}$ \\
\hline $\begin{array}{l}\stackrel{\mathrm{O}-\mathrm{CH}_{2}-\mathrm{CH}_{3}}{\mathrm{l}} \mathrm{H}_{2} \mathrm{~N}-\mathrm{H}_{2} \mathrm{C}-\mathrm{H}_{2} \mathrm{C}-\mathrm{H}_{2} \mathrm{C}-\mathrm{Si}-\left(\mathrm{O}-\mathrm{CH}_{2}-\mathrm{CH}_{2}-\mathrm{NH}_{2}\right)_{2} \\
\text { 3-aminopropyl-di- (2-aminoethoxy) } \\
\text { ethoxysilane (II) }\end{array}$ & $2: 1$ & 95.7 & 1.4521 & $\begin{array}{l}3366,3293 \\
\left(\mathrm{NH}_{2}\right), 2971 \\
2927,2875 \\
\left(\mathrm{CH}_{3}, \mathrm{CH}_{2}\right) \\
1081(\mathrm{Si}-\mathrm{O}-\mathrm{C})\end{array}$ \\
\hline $\begin{array}{l}\mathrm{H}_{2} \mathrm{~N}-\mathrm{H}_{2} \mathrm{C}-\mathrm{H}_{2} \mathrm{C}-\mathrm{H}_{2} \mathrm{C}-\mathrm{Si}-\left(\mathrm{O}-\mathrm{CH}_{2}-\mathrm{CH}_{2}-\mathrm{NH}_{2}\right)_{3} \\
\text { 3-aminopropyl-tri- (2-aminoethoxy) silane } \\
\text { (III) }\end{array}$ & $3: 1$ & 97.6 & 1.4650 & $\begin{array}{l}1590(\mathrm{Si}-\mathrm{O}-\mathrm{C}) \\
3362,3293 \\
\left(\mathrm{NH}_{2}\right) \\
1083-1020 \\
(\mathrm{Si}-\mathrm{O})\end{array}$ \\
\hline
\end{tabular}


and an alkali metal alcoholate. The mixture is kept at room temperature for $10 \mathrm{~min}$ utes, then evacuated at temperature up to $100{ }^{\circ} \mathrm{C}$ for $10-20$ minutes, until the alcohol is completely removed.

Data on the synthesis of aminosiloxanes are given in Table 1.

The process was monitored by IR spectroscopy on an FT-801 Fourier spectrophotometer. In the IR spectra of the obtained products, there are intense absorption bands at $1081-1085 \mathrm{~cm}^{-1}$, characteristic of Si-O-C bonds. The bands of the hydroxyl group directly bonded to the silicon atom are absent, and the bands corresponding to the $\mathrm{NH}_{2}$-group are observed at $3275-3373 \mathrm{~cm}^{-1}$. Aminosiloxanes are clear to light yellow oily liquids.

Further, with the use of synthesized aminosiloxanes, flux compositions were obtained. Citric acid is dissolved in an isopropyl alcohol, glycerol is added, and synthesized aminosiloxane of the general formula is introduced into the resulting mixture,
$\stackrel{\left(\mathrm{O}-\mathrm{CH}_{2}-\mathrm{CH}_{3}\right)_{(3-\mathrm{n})}}{\mathrm{H}_{2} \mathrm{~N}-\mathrm{H}_{2} \mathrm{C}-\mathrm{H}_{2} \mathrm{C}-\mathrm{H}_{2} \mathrm{C}-\stackrel{\mathrm{S}}{\mathrm{Si}}-\left(\mathrm{O}-\mathrm{CH}_{2}-\mathrm{CH}_{2}-\mathrm{NH}_{2}\right)_{\mathrm{n}}}$ mixed well.

Citric acid, isopropyl alcohol and glycerin are classified as hazard class 4 , are of natural origin and biodegradable, so they have a minimal impact on the environment.

The compositions of the flux for soldering and tinning are given in Table 2.

The viscosity of the flux for soldering and tinning copper wire, according to the compositions (Table 2) are determined in accordance with GOST 6258-85. The activity of the flux (spreading coefficient) of POIN-52 solder on copper plates at a temperature of $150 \pm 30^{\circ} \mathrm{C}$ is calculated as the ratio of the spreading area of the solder under the action of the inventive flux to the spreading area of the solder under the action of the inventive flux in the form of a $20 \%$ solution in isopropyl alcohol. The absolute error in determining the activity of fluxes at a probability of 0.95 is \pm 0.03 , the error in measuring the temperature of the solder is $\pm 2{ }^{\circ} \mathrm{C}$.

\section{Results and discussion}

The test results are shown in Table 3. ity, which provides a significant increase

According to above data the proposed flux compositions have good fluxing activin the adhesion strength of the coating, improves the quality of tinning due to bet-

Table 2

Compositions of flux for soldering and tinning copper wire

\begin{tabular}{c|c|c|c}
\hline \multirow{2}{*}{ Components, wt. \% } & \multicolumn{3}{|c}{ Flux } \\
\cline { 2 - 4 } & 1 & 2 & 3 \\
\hline Citric acid & 12 & 15 & 5 \\
\hline Glycerol & 10 & 8 & - \\
\hline Aminosiloxane 1 & 3 & - & - \\
\hline Aminosiloxane 2 & - & 2 & 1 \\
\hline Aminosiloxane 3 & - & - & others \\
\hline Isopropyl alcohol & others & others & \\
\hline
\end{tabular}


ter spreading of the solder, that ensures continuous tinning of the copper plate and the absence of corrosion and are also easily biodegradable.

The use of flux to obtain an electrode for the solar module showed that during the production process, smoke does not accumulate over the tinning bath, splashing of tin and its alloys decreases. When the tinned copper wire is twisted, cracks and chips do not form, and the coating does not peel off.

Table 4 shows the test results of tinned copper wire using a flux.

Table 3

Test results of flux for soldering and tinning copper wire

\begin{tabular}{c|c|c|c|c}
\hline \multirow{2}{*}{ Flux } & \multicolumn{2}{|c|}{ Test results of flux for soldering and tinning copper wire } & \multirow{2}{*}{$\begin{array}{c}\text { Biodegradation } \\
\text { after 28 days, \% }\end{array}$} \\
\cline { 2 - 4 } & Fluxing activity, mm & Spread coefficient & Wettability $\theta,{ }^{\circ}$ & 72 \\
\hline 1 & 95.56 & 2.86 & 14 & 64 \\
\hline 2 & 99.16 & 2.91 & 12 & 60 \\
\hline 3 & 110.47 & 2.97 & 10 & \\
\hline
\end{tabular}

Tinned copper wire test results

Table 4

\begin{tabular}{|c|c|c|c|c|}
\hline \multirow{2}{*}{$\begin{array}{l}\text { Indicator name, unit } \\
\text { of measurement }\end{array}$} & \multicolumn{4}{|c|}{ Tinned wire POIN-52 alloy } \\
\hline & $\begin{array}{l}\text { Normalized value } \\
\text { (TT) }\end{array}$ & \multicolumn{3}{|c|}{ Test results } \\
\hline Appearance & $\begin{array}{l}\text { smooth surface and } \\
\text { continuous coating } \\
\text { along the entire } \\
\text { length of the wire }\end{array}$ & $\begin{array}{l}\text { the surface } \\
\text { is smooth } \\
\text { and clean, } \\
\text { the coating } \\
\text { is continuous }\end{array}$ & $\begin{array}{l}\text { the surface } \\
\text { is smooth } \\
\text { and clean, } \\
\text { the coating } \\
\text { is continuous }\end{array}$ & $\begin{array}{l}\text { the surface } \\
\text { is smooth } \\
\text { and clean, } \\
\text { the coating } \\
\text { is continuous }\end{array}$ \\
\hline Diameter, mm & $0.25_{-0.005}^{+0.005}$ & 0.249 & 0.254 & 0.252 \\
\hline $\begin{array}{l}\text { Coating thickness, } \\
\text { microns }\end{array}$ & $3.5_{-0.001}^{+0.001}$ & 3.3 & 3.5 & 3.4 \\
\hline Density, $\mathrm{g} / \mathrm{cm}^{3}$ & $8.9 \pm 0.2$ & 9.0 & 9.0 & 9.0 \\
\hline $\begin{array}{l}\text { Tensile strength } \\
\text { of wire, } \mathrm{N} / \mathrm{mm}^{2}\end{array}$ & $200-290$ & 240 & 244 & 244 \\
\hline Relative extension, $\%$ & $25_{-10}^{+5}$ & 21 & 21 & 21 \\
\hline $\begin{array}{l}\text { DC electrical } \\
\text { resistance at } 20^{\circ} \mathrm{C} \text {, } \\
\mathrm{Ohm} / \mathrm{m} .\end{array}$ & $0.35 \pm 0.03$ & 0.35 & 0.35 & 0.35 \\
\hline $\begin{array}{l}\text { Direct current } \\
\text { electrical resistivity } \\
\text { at } 20^{\circ} \mathrm{C}, \mathrm{Ohm} \\
\mathrm{mm}^{2} / \mathrm{m} \text {. }\end{array}$ & $0.017 \pm 0.002$ & 0.0176 & 0.0176 & 0.0176 \\
\hline
\end{tabular}




\section{Conclusions}

According to the above data, test results show that the obtained data of the finished tinned copper wire fully comply with the standards, and the flux can be used in the manufacture of electrodes for solar cells.

In this way,

1. Biodegradable aminosiloxanes have been synthesized and used as active fluxing additives in the development of flux.

2. The qualitative and quantitative composition of the flux for tinning copper wire and the production of electrodes for solar modules was selected, which is based on the use of environmentally friendly substances based on natural, biodegradable raw materials.
3. It has been found that the synthesized aminosiloxanes increase the wetting ability, fluxing activity and also the biodegradability of the flux.

4. As a result of using the developed compositions of fluxes, the gas contamination of industrial premises decreases, the likelihood of injury and burns decreases.

5. Using the developed flux for hot tinning of copper wire with low-melting lead-free solder POIN-52 allows obtaining an electrode for solar panels with high physical, mechanical and operational properties.

6. Improving the environmental friendliness of the production of electrodes for solar panels is achieved by a set of the above measures.

\section{Acknowledgements}

The research was carried out by Chuvash state University within the implementation of a comprehensive project under the contract No. 2019/0837/1202-19 dated September 19, 2019 with the financial support of the Ministry of Education and Science of Russia under the Agreement No. 075-11-2019-047 dated November 25, 2019.

\section{References}

1. Zarmai MT, Ekere NN, Oduoza CF, Amalu EH. A review of interconnection technologies for improved crystalline silicon solar cell photovoltaic module assembly. Applied Energy. 2015;154:173-82.

doi:10.1016/j.apenergy.2015.04.120

2. Miles RW. Photovoltaic solar cells: choice of materials and production methods. Vacuum. 2006;80(10):1090-7. doi:10.1016/j.vacuum.2006.01.006

3. Saga T. Advances in crystalline silicon solar cell technology for industrial mass production. NPG Asia Mater. 2010;2(3):96-102.

doi:10.1038/asiamat.2010.82

4. Fazal MA, Liyana NK, Rubaiee S, Anas A. A critical review on performance, microstructure and corrosion resistance of Pb-free solders. Measurement. 2019;134:897907.

doi:10.1016/j.measurement.2018.12.051

5. Li G, Akram MW, Jin Y, Chen X, Zhu C, Ahmad A, Arshad RH, Zhao X. Thermomechanical behavior assessment of smart wire connected and busbar PV modules 
during production, transportation, and subsequent field loading stages. Energy. 2019;168:931-45.

doi:10.1016/j.energy.2018.12.002

6. Campeau Z, Anderson M, Hasselbrink E, Kavulak D, Shen YC, Lacerda R. SunPower ${ }^{\circledR}$ module degradation rate [Internet]. SunPower Corpor. 2013 [cited 29.10.2020]; p. 1-61. Available from: https://energyhub.org/wp-content/uploads/2018/05/SunPowerModule-Degredation-PDF.pdf

7. Jeong JS, Park N, Han C. Field failure mechanism study of solder interconnection for crystalline silicon photovoltaic module. Microelectronics Reliability. 2012;52(910):2326-30.

doi:10.1016/j.microrel.2012.06.027

8. Chen YM, Chiu YP, Wu H. Improved testing of soldered interconnects quality on silicon solar cell. GPEM. 2020;1(2):51-8.

9. Ryzhova OG, Fokina IV, Mukhamedzhanova TG, Churmasova LI, Indisova GE, Shanenko EF. Kremniyorganicheskie soedineniya, povishayushchie effektivnost' ochistki stochnykh vod [Organosilicon compounds that increase the efficiency of wastewater treatment]. Khimicheskaya promyshlennost' segodnya [Chemical industry today]. 2018;6:9-12. Russian. 